\title{
Rainforest disturbance affects population density of the northern cassowary Casuarius unappendiculatus in Papua, Indonesia
}

\author{
Margaretha Pangau-A dam, Michael Mühlenberg and Matthias Waltert
}

\begin{abstract}
Nominally protected areas in Papua are under threat from encroachment, logging and hunting. The northern cassowary Casuarius unappendiculatus is the largest frugivore of the lowland rainforest of New Guinea and is endemic to this region, and therefore it is an important conservation target and a potential flagship species. We investigated effects of habitat degradation on the species by means of distance sampling surveys of 58 line transects across five distinct habitats, from primary forest to forest gardens. Estimated cassowary densities ranged from 14.1 (95\% CI 9.2-21.4) birds $\mathrm{km}^{-2}$ in primary forest to 1.4 (95\% CI 0.4-5.6) birds $\mathrm{km}^{-2}$ in forest garden. Density estimates were intermediate in unlogged but hunted natural forest and in $>30$ year-old secondary forest, and considerably lower in recently logged ( $<3$ years) forest. Cassowary abundance was positively correlated with canopy cover and with tree height and diameter, and negatively correlated with hunting traps and human trails. In generalized linear models cassowary abundance was best explained by the number of fruiting trees and potential water sources. The results suggest that although the northern cassowary is moderately tolerant of intermediate disturbance it is relatively intolerant of heavy disturbance such as intensive logging. To secure the populations of northern cassowary and of other large animal species in Papua, forest degradation needs to be addressed by enforcing regulations in existing protection forest and/or establishing new protected areas, such as wildlife reserves.
\end{abstract}

Keywords Deforestation, density estimation, detection probability, frugivore, Indonesia, logging, northern cassowary, protected area

\section{Introduction}

7 he rainforest of New Guinea is recognized as one of the I last remaining wilderness areas but rapid development

Margaretha Pangau-Adam* (Corresponding author), Michael Mühlenberg and Matthias Waltert Department of Conservation Biology, JohannFriedrich-Blumenbach Institute of Zoology, Georg-August-Universität Göttingen, Bürgerstrasse 50, 37073 Göttingen, Germany

E-mail mpangau1@gwdg.de

${ }^{*}$ Current address: Biology Department, Faculty of Natural Sciences and Mathematics, Cenderawasih University, Papua, Indonesia

Received 1 April 2013. Revision requested 16 July 2013.

Accepted 22 October 2013. First published online zo July 2014. and human population growth are leading to high rates of deforestation and forest conversion. Besides disturbance from logging, large-scale oil palm plantations are the primary cause of the loss of lowland forest in Papua (Frazier, 2007). A number of conservation areas and protection forests have been established in this region (de Fretes, 2007) but agricultural encroachment, illegal logging and hunting by immigrants and local communities are common. As in other parts of the tropics, local extinction of forest avifauna following forest fragmentation and extensive forest clearing is to be expected (Kattan et al., 1994; Castelletta et al., 2000; Waltert et al., 2004). Large forest birds such as cassowaries (Casuarius spp.) are particularly likely to disappear if their habitat is disturbed, as their persistence may depend on factors such as the presence of fruiting trees and water sources (Bentrupperbäumer, 1997). Cassowaries are flightless, obligate frugivores and as such they require abundant fruit on the forest floor, a resource that is in short supply or absent in logged or converted forest. Their long-term viability probably depends on the preservation of sufficiently large tracts of forest (Moore, 2003). Roads associated with new logging concessions provide hunters with access to previously remote forest areas. Cassowaries are particularly sought by hunters because of their large body size, and in some areas they are under considerable pressure from hunting (Mack \& West, 2005; Pangau-Adam \& Noske, 2010).

The northern cassowary Casuarius unappendiculatus is endemic to the lowlands of northern New Guinea. This species has two relatives: the dwarf cassowary Casuarius bennetti, which inhabits the montane areas of New Guinea and New Britain, and the southern cassowary Casuarius casuarius of southern New Guinea and north-east Australia. The northern cassowary is New Guinea's largest bird, with height up to $1.5 \mathrm{~m}$ and weight of $25-60 \mathrm{~kg}$, and inhabits lowland and swamp forests up to $700 \mathrm{~m}$ altitude (Coates, 1985; Beehler et al., 1986). Unlike the southern cassowary, the northern cassowary has not been studied in the field and its ecology is therefore poorly known (BirdLife International, 2013).

Cassowaries play a significant role as the major seed dispersers of numerous rainforest plants. All cassowary species are obligate frugivores (Crome, 1976; Stocker \& Irvine, 1983), with fruit constituting 90-99\% of their diet (Bentrupperbäumer, 1997; Wright, 2005). In Papua New Guinea the dwarf cassowary was found to be an important seed disperser for large-fruited plants and appeared to be 


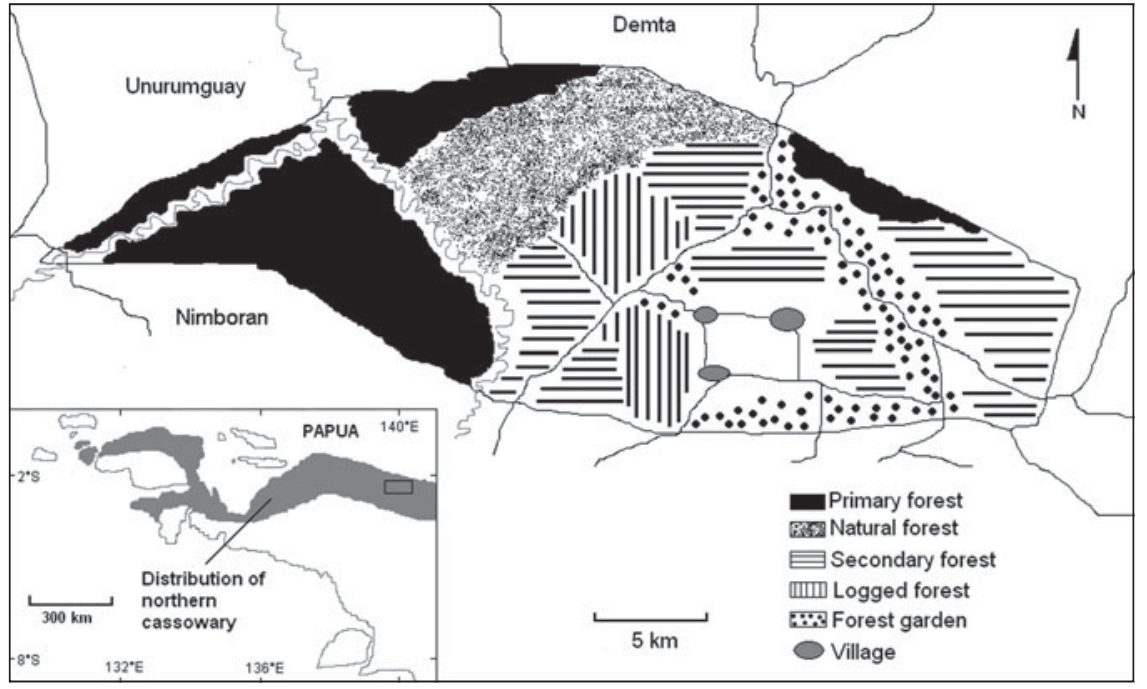

FIG. 1 The various habitat types in the study area in northern Papua, Indonesia. The inset shows the distribution of the northern cassowary Casuarius unappendiculatus, with a rectangle marking the location of the main map. the keystone frugivore for 67 species (Mack \& Wright, 2005). In North Queensland the southern cassowary is the only major dispersal agent of c. 100 rainforest plants (Crome \& Moore, 1990). It is reasonable to assume, therefore, that the northern cassowary is the largest and principal seed disperser of many lowland forest plants in northern New Guinea (Beehler et al., 1995), making it an important target species for conservation, and a potential flagship species.

Despite its significant ecological role and ongoing rapid deforestation in Papua there have been no systematic assessments of the population status of the northern cassowary or of its response to disturbance. The aims of this study are to assess cassowary density in various habitat types along a forest disturbance gradient of northern Papua, to examine the relationship between cassowary abundance and habitat variables, especially those related to anthropogenic activities, and to discuss the implications for forest conservation strategies in Papua.

\section{Study area}

The study was conducted in Nimbokrang, c. $110 \mathrm{~km}$ west of Jayapura, the capital of Papua Province, Indonesia (Fig. 1). The Nimbokrang lowlands contain a mosaic of forest habitats, including large areas of intact forest. As a result of its high diversity of endemic birds, Nimbokrang forest has become an internationally renowned bird-watching destination. Typical canopy tree genera are Intsia, Pometia, Ficus, Canarium, Alstonia and Terminalia, and understory trees include Myristica, Syzygium, Garcinia, Diospyros, Pandanus and palms. Significant areas of the forest are claimed as traditional or clan forest by local people, resulting in several different land-use systems, including shifting cultivation and forest garden.

The study area comprises $304 \mathrm{~km}^{2}$ of continuous lowland forest and was chosen based on the availability of different habitat types representing a gradient of disturbance from undisturbed primary forest to unlogged but hunted natural forest, $>$ 30-year-old secondary forest, logged forest and forest garden. Primary forest is defined here as forest that has reached a steady state without significant disturbance. Natural forest is original forest with infrequent collecting of non-timber forest products (NTFP) and subsistence wildlife hunting by local people. Secondary-growth forest was logged selectively $>30$ years prior to this study and is now entered frequently by local people for hunting, bird trapping and NTFP collection. Logged forest habitat is selectively logged forest $<_{3}$ years old. Forest garden is secondary forest and/or abandoned logged forest that contains a mixture of cultivated plant species and forest vegetation.

\section{Methods}

All fieldwork was carried out during May 2011-April 2012 by MP-A and four local field assistants.

Surveys were conducted using the line transect method (Buckland et al., 2001). In each habitat 10-14 transects were established, at least $500 \mathrm{~m}$ apart, with a total of 58 transects. Transects were $0.8-3 \mathrm{~km}$ in length and each transect was walked in the morning (06.30-11.30) and afternoon (13.00-17.00) during 2011-2012. For each direct encounter of a cassowary we measured the perpendicular distance from the bird (or from its estimated position at detection) to the transect. Most sightings were of single individuals; only 5 of 95 encounters were with an adult bird with chicks. Distance data were therefore analysed using single individuals as the sampling unit. We used DISTANCE v. 6.2 (Buckland et al., 2001) to model a global detection probability, using habitat as a covariate to estimate cassowary density for each habitat. We calculated an overall density based on stratum estimates, weighted by stratum area, 
as well as effective strip width $(\mu)$, defined as the distance from the line at which as many animals are detected beyond $\mu$ as are missed within $\mu$ (Buckland et al., 2001). We investigated the relationship between cassowary abundance and habitat variables, with univariate and multivariate analyses, using numbers of bird encounters per transect after they were standardized for equal survey effort.

Habitat variables were measured and analysed at transect level, with habitat as the grouping variable. The circular plot method was used to collect vegetation data. At least three plots of 5-m radius were established $30 \mathrm{~m}$ from, and perpendicular to, either side of each transect. Within each plot the diameter at breast height $(\mathrm{DBH})$ was measured and the height of all trees with $\mathrm{DBH} \geqslant 10 \mathrm{~cm}$ estimated. At the centre of each plot the percentage of vegetation cover was estimated visually at three strata: ground level $\left(<_{1} \mathrm{~m}\right)$, understorey level $(1-5 \mathrm{~m})$ and canopy level, and the mean was calculated for each transect.

Differences in vegetation parameters between habitats were tested using the Kruskal-Wallis test and the P-values were adjusted using the Bonferroni correction (Fahrmeir et al., 2010). We also assessed bivariate relationships between cassowary abundance and vegetation variables, using Spearman rank correlations. As measures of forest disturbance we counted human trails and hunting traps encountered along each transect, and measured the distance from the starting point of each transect to the nearest village.

To determine the suitability of habitat for cassowaries we counted all fruiting trees with fruits $>1 \mathrm{~cm}$ diameter within $15 \mathrm{~m}$ of the transect. We also collected fresh droppings of cassowaries at each site and identified the seeds present in the samples, to facilitate the comparison of consumed plant species with tree species known to fruit during the survey periods. Because water sources are amongst the most important factors for cassowaries (Crome \& Moore, 1990; Bentrupperbäumer, 1997) we quantified the number of swamp pools, streams and other water sources during the survey. To analyse the influence of habitat requirements and distance from village on cassowary abundance a covariate analysis was performed using generalized linear modeling in $R$ v. 2.12.1 (R Development Core Team, 2011). Given the low number of cassowary records in forest gardens, this habitat type was excluded from this analysis.

\section{Results}

\section{Cassowary density}

Cassowaries were encountered on all transects in primary and natural forest, 13 of 14 transects in secondary forest, and seven of 10 transects in logged forest, but on only two of 10 transects in forest gardens. A total of 95 cassowaries (56 adults, 28 subadults and 11 chicks) were located during the survey, with $292 \mathrm{~km}$ of survey effort. Density estimates varied among habitat types, the highest being 14.1 individuals $\mathrm{km}^{-2}$ (95\% CI 9.2-21.4) in primary forest and the lowest 1.4 individuals $\mathrm{km}^{-2}$ (95\% CI $0.4-5.6$ ) in forest garden. Densities were intermediate in natural forest $\left(7.7 \mathrm{~km}^{-2}, 95 \% \mathrm{CI} 4.5-13.0\right)$ and in $>30$-year-old secondary forest $\left(9.8 \mathrm{~km}^{-2}, 95 \% \mathrm{CI} 5.5-17.3\right)$ but were considerably lower in recently logged ( $<3$ years) forest $\left(4.2 \mathrm{~km}^{-2}, 95 \% \mathrm{CI}\right.$ 2.1-8.4; Table 2). Combining the data from all habitats the overall density estimate was 8.5 individuals $\mathrm{km}^{-2}(95 \%$ CI 6.5-11.1) or 3.9 adult individuals $\mathrm{km}^{-2}$ (95\% CI 2.8-5.4).

\section{Vegetation parameters and anthropogenic activities}

Almost all habitat variables differed significantly between habitat types (Table 3). Primary forest had a significantly higher mean canopy cover $(74.8 \%)$, tree height $(H=20.6 \mathrm{~m})$ and tree diameter $(D=31.1 \mathrm{~cm})$ and significantly lower understorey and ground cover (40.0 and $26.6 \%$, respectively) than the other habitats (Table 3 ). Mean canopy cover of natural forest $(71 \%)$ was not significantly different from that of primary forest. Secondary forest showed intermediate values for vertical levels of vegetation cover and tree height but had a mean tree diameter similar to logged forest (24.7 and $22.2 \mathrm{~cm}$, respectively). Logged forest had a lower mean tree diameter, tree height and canopy cover, and forest garden had the smallest and shortest trees and sparsest canopy cover (Table 3 ).

Mean numbers of fruiting trees were highest in primary forest (17.4 $\pm \mathrm{SD} 7.6$ ), followed by natural and secondary forest (14.5 $\pm \mathrm{SD} 6.4$ and $12.1 \pm \mathrm{SD} 7.2$, respectively). Low numbers of fruiting trees were counted in logged forest, with the lowest number in forest garden (Fig. 2). Cassowaries were observed feeding on tree species of the families Palmae, Pandanaceae, Myrtaceae, Lauraceae and Combretaceae and, including the records from faecal analysis, 23 families and 61 species of fruiting trees were found in the cassowary's diet (Table 1). They were also observed drinking water in swamp pools, in small streams and rivers. These water sources were found more frequently in primary forest, followed by natural forest and secondary forest, and less frequently in logged forest and forest garden (Table 3). Few human trails and no wildlife traps were found in primary forest, intermediate numbers of each were found in natural forest and secondary forest, and the highest numbers were found in logged forest and forest garden (Table 3).

\section{Relationships between cassowary abundance and habitat variables}

Cassowary abundance, measured as the number of encounters per transect, was strongly correlated with canopy cover $\left(r_{s}=0.76, \mathrm{P}<0.05\right)$, and moderately correlated with tree height and diameter $\left(r_{s}=0.52, \mathrm{P}<0.05\right.$ and 
TABLE 1 Species of feeding trees recorded from faecal samples of northern cassowary Casuarius unappendiculatus, collected in different habitats in northern Papua, Indonesia (Fig. 1).

\begin{tabular}{|c|c|}
\hline Family & Species \\
\hline Anacardiaceae & $\begin{array}{l}\text { Pleiogynium timorense } \\
\text { Semecarpus magnificus } \\
\text { Spondias cytherea }\end{array}$ \\
\hline Apocynaceae & $\begin{array}{l}\text { Cerbera floribunda } \\
\text { Cerbera inflate }\end{array}$ \\
\hline Arecaceae/Palmae & $\begin{array}{l}\text { Actinorhytis calapparia } \\
\text { Areca macrocalyx } \\
\text { Borassus heineanus } \\
\text { Caryota rumphiana } \\
\text { Calamus aruensis } \\
\text { Licuala sp. } \\
\text { Licuala lauterbachii } \\
\text { Metroxylon sagu } \\
\text { Orania sp. } \\
\text { Ptychococcus paradoxus }\end{array}$ \\
\hline Barringtoniaceae & Barringtonia calyptrata \\
\hline Burseraceae & $\begin{array}{l}\text { Canarium kaniense } \\
\text { Canarium vitiense }\end{array}$ \\
\hline Clusiaceae & $\begin{array}{l}\text { Garcinia latissima } \\
\text { Garcinia sp. }\end{array}$ \\
\hline Combretaceae & $\begin{array}{l}\text { Terminalia copelandii } \\
\text { Terminalia impediens } \\
\text { Terminalia complanata } \\
\text { Terminalia kaernbachii } \\
\text { Terminalia sp. }\end{array}$ \\
\hline Elaeocarpaceae & $\begin{array}{l}\text { Elaeocarpus sp. } 1 \\
\text { Elaeocarpus sp. } 2\end{array}$ \\
\hline Fabaceae & $\begin{array}{l}\text { Millettia pinnata } \\
\text { Mucuna sp. }\end{array}$ \\
\hline Gnetaceae & $\begin{array}{l}\text { Gnetum gnemon } \\
\text { Gnetum sp. }\end{array}$ \\
\hline Icacinaceae & Ryticaryum longifolium \\
\hline Lauraceae & $\begin{array}{l}\text { Cryptocarya sp. } \\
\text { Endiandra microneura }\end{array}$ \\
\hline Meliaceae & Aglaia sp. \\
\hline Menispermaceae & $\begin{array}{l}\text { Albertisia papuana } \\
\text { Arcangelisia tympanopida } \\
\text { Chlaenandra ovata } \\
\text { Macrococculus sp. }\end{array}$ \\
\hline Moraceae & $\begin{array}{l}\text { Ficus congesta } \\
\text { Ficus variegata } \\
\text { Ficus sp. } \\
\text { Artocarpus altilis }\end{array}$ \\
\hline Myrtaceae & $\begin{array}{l}\text { Syzygium aqueum } \\
\text { Syzygium forte } \\
\text { Syzygium sp. } 1 \\
\text { Syzygium sp. } 2\end{array}$ \\
\hline Myristicaceae & $\begin{array}{l}\text { Myristica sp. } \\
\text { Horsfieldia sp. }\end{array}$ \\
\hline Pandanaceae & $\begin{array}{l}\text { Pandanus conoideus } \\
\text { Pandanus papuanus } \\
\text { Pandanus tectorius } \\
\text { Pandanus sp. }\end{array}$ \\
\hline Rubiaceae & $\begin{array}{l}\text { Versteegia cauliflora } \\
\text { Morinda citrifolia }\end{array}$ \\
\hline
\end{tabular}

Table 1 (Cont.)

\begin{tabular}{ll}
\hline Family & Species \\
\hline Sapindaceae & Pometia pinnata \\
& Pometia sp. \\
Sapotaceae & Palaquium sp. \\
Tiliaceae & Microcos sp. \\
Unknown & Liana sp. 1 \\
& Liana sp. 2 \\
\hline
\end{tabular}

$r_{s}=0.57, \mathrm{P}<0.05$, respectively). In contrast, cassowary abundance was moderately to strongly negatively correlated with wildlife traps $\left(r_{s}=-0.67, \mathrm{P}<0.05\right)$, human trails $\left(r_{s}=-0.78, \quad \mathrm{P}<0.05\right)$, understorey vegetation cover $\left(r_{s}=-0.60, \mathrm{P}<0.05\right)$ and ground vegetation cover $\left(r_{s}=-0.67, \mathrm{P}<0.05\right)$. The mean distance from transects to the nearest village was significantly different between habitat types $(H=36.94, \mathrm{df}=4, \mathrm{n}=58, \mathrm{P}<0.01)$, ranging from a mean of $3.94 \mathrm{~km}$ in forest gardens to $11.78 \mathrm{~km}$ in primary forest. This variable was moderately correlated with cassowary abundance $\left(r_{s}=0.62, \mathrm{P}<0.05\right)$.

As with density estimates, cassowary abundance also differed significantly between habitats $(H=21.49$, $\mathrm{df}=4$, $\mathrm{n}=58, \mathrm{P}<0.01)$. However, natural forest and secondary forest had similar mean encounter rates, as had logged forest and forest garden (Table 2). In the multivariate analysis cassowary abundance was significantly influenced by the number of fruiting trees and potential water sources, and the interaction between these variables had a marginally significant effect (Table 4). The variable 'distance to village' was excluded from the model because of non-significant results.

\section{Discussion}

\section{Cassowary density}

Our density estimate for the northern cassowary (3.9 adults $\mathrm{km}^{-2}$ ) is higher than that inferred from the BirdLife International (2013) data for this species (c. 0.010.05 adult birds $\mathrm{km}^{-2}$ across its global range). It is also higher than that of Moore (2007), who estimated 0.48 adults $\mathrm{km}^{-2}$, but similar to that of Bentrupperbäumer (1997), who estimated 3.8 adults $\mathrm{km}^{-2}$ (both for the southern cassowary). In calculating cassowary density, Bentrupperbäumer (1997) sampled small areas $\left(<_{4} \mathrm{~km}^{2}\right)$ in the Mission Beach region of North Queensland, whereas Moore (2007) surveyed a large area $\left(102 \mathrm{~km}^{2}\right)$ in the same region, suggesting that small sampling areas may have led to overestimation of cassowary density. We covered a study area of $304 \mathrm{~km}^{2}$, accumulating 56 observations of adult cassowaries. Comparing our results with those of 


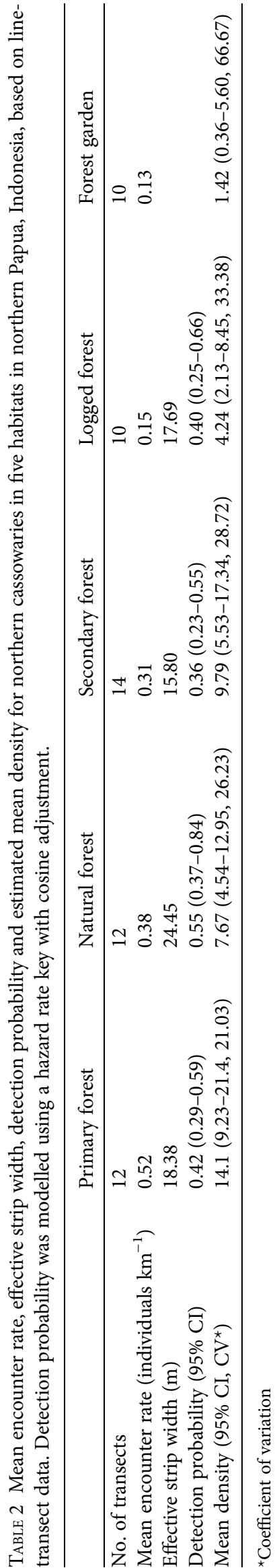

Moore (2007) we cautiously conclude that our density estimate of northern cassowaries is higher than that of its southern counterpart in Australia. One possible reason for this difference is that our study area is embedded in large, continuous tracts of undisturbed primary rainforest, which provide abundant food and water resources. In contrast, much of the rainforest habitat of the southern cassowary in North Queensland is fragmented and this has resulted in population decline and local extirpation (Crome \& Moore, 1990; Latch, 2007). Moreover, many southern cassowaries in Australia are killed by dogs or, accidentally, by motorists (Latch, 2007) but these causes of mortality are absent in the northern lowlands of Papua.

\section{Effects of habitat on density estimates}

The northern cassowary was detected in each habitat type, showing that the species can use a complex array of habitats, including logged forest and forest garden. Nevertheless the variation in population density estimates between these habitats suggests it is sensitive to habitat alteration. The highest density was found in undisturbed habitat and the lowest in logged forest and forest garden, where the level of disturbance was highest. Moderately disturbed habitats supported intermediate densities. These results suggest that the northern cassowary may be tolerant of moderate disturbance but intolerant of severe disturbance. Damage to habitat, including the loss of canopy cover and other forest vegetation, was also found to be detrimental to the southern cassowary (Crome \& Moore, 1990).

Logging may be the biggest threat to the studied population of northern cassowary. Unsustainable logging practices can destroy the forest canopy and reduce the quality of the habitat for cassowaries, especially if food plants are removed. Most of the differences in cassowary density between habitats may be attributed to the variation in food availability and vegetation structure. Fruit availability is considered to be a major factor influencing population dynamics in frugivorous animals (e.g. Innis, 1989; Bentrupperbäumer, 1997). The highest density of cassowaries was found in primary forest, where fruiting trees were most abundant. Because access to the primary forest is relatively difficult, this forest area has not been exploited for timber, and therefore the natural vegetation there still provides abundant food sources, particularly large trees that produce large fruits (Takeuchi, 2007; Waromi, 2011, pers. comm.). The areas of natural forest have low levels of disturbance and are visited by hunters only rarely, so the vegetation structure and abundance of fruiting trees are similar to primary forest. Most of the secondary forest surveyed is still recovering from past disturbance but this habitat already provides sufficient food sources for cassowaries. The abundance of fruiting trees in moderately disturbed habitats may be attributable to improved light 
TABLE 3 Mean values of \% canopy cover, \% understorey cover, \% ground cover, tree height, diameter at breast height (DBH), numbers of water sources, human trails and hunting traps, and P-values for each of the five habitat types studied.

\begin{tabular}{|c|c|c|c|c|c|c|}
\hline & Primary forest & Natural forest & Secondary forest & Logged forest & Forest garden & $\begin{array}{l}\text { Kruskal- } \\
\text { Wallis P }\end{array}$ \\
\hline Canopy cover (\%) & $74.83 \pm \mathrm{SD} 6.56$ & $71 \pm$ SD 7.59 & $66.14 \pm$ SD 4.29 & $41.2 \pm$ SD 10.6 & $26.5 \pm$ SD 7.01 & $<0.01$ \\
\hline Understorey cover $(\%)$ & $40.0 \pm \mathrm{SD} 5.49$ & $45.58 \pm$ SD 5.99 & $51.0 \pm$ SD 9.71 & $58.0 \pm \mathrm{SD} 7.82$ & $57.4 \pm$ SD 5.27 & 0.01 \\
\hline Ground cover $(\%)$ & $26.58 \pm$ SD 6.2 & $31.92 \pm$ SD 5.05 & $36.5 \pm$ SD 13.51 & $56.7 \pm$ SD 10.53 & $68.2 \pm$ SD 10.76 & $<0.01$ \\
\hline Tree height (m) & $20.65 \pm$ SD 1.64 & $17.33 \pm \mathrm{SD} 2.02$ & $16.29 \pm$ SD 2.27 & $11.8 \pm$ SD 1.67 & $8.28 \pm$ SD 1.33 & $<0.01$ \\
\hline $\mathrm{DBH}(\mathrm{cm})$ & $31.1 \pm \mathrm{SD} 3.28$ & $27.56 \pm \mathrm{SD} 4.53$ & $24.65 \pm$ SD 4.8 & $22.24 \pm \mathrm{SD} 3.81$ & $15.83 \pm \mathrm{SD} 3.35$ & $<0.01$ \\
\hline Water sources & $4.33 \pm \mathrm{SD} 2.02$ & $3.42 \pm$ SD 1.88 & $2.86 \pm$ SD 1.92 & $1.0 \pm$ SD 0.94 & $0.5 \pm$ SD 0.85 & $<0.01$ \\
\hline Human trails & $0.17 \pm \operatorname{SD} 0.39$ & $0.83 \pm \mathrm{SD} 0.72$ & $1.28 \pm \mathrm{SD} 0.83$ & $1.90 \pm$ SD 0.99 & $1.90 \pm$ SD 0.57 & $<0.01$ \\
\hline Hunting traps & 0 & $0.5 \pm$ SD 0.52 & $0.64 \pm$ SD 0.83 & $1.10 \pm$ SD 0.88 & $0.80 \pm \mathrm{SD} 0.74$ & 0.05 \\
\hline
\end{tabular}

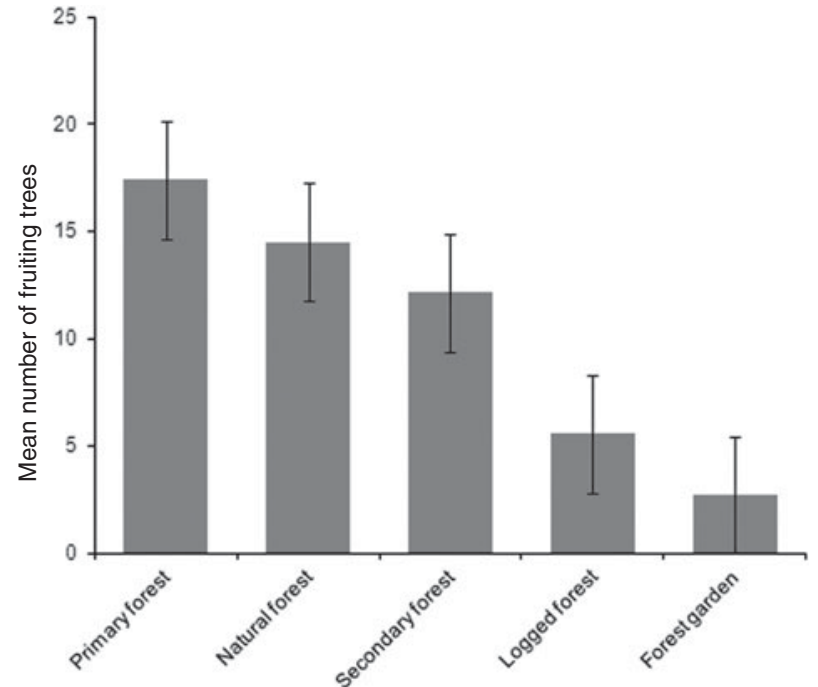

FIG. 2 Mean number of fruiting trees per $2.5 \mathrm{~km}$ transect in each habitat. Error bars are standard errors.

conditions after the opening of forest canopy (e.g. for Neotropical forests: Gomes et al., 2008; Lefevre, 2008). However, the tree species composition of forest disturbed by logging is different from that of primary forest, being characterized by more light-demanding plants and probably resulting in different spatio-temporal availability of fruit and the complete loss of certain fruiting trees. Many Papuan forest trees that produce large fruits (e.g. Terminalia spp. and Canarium spp.) also have high-quality timber and are therefore the first to be extracted (Forestry Services of Papua Province, 2001).

Another important factor influencing the density of cassowaries is water availability. Water sources were found to a lesser extent in heavily disturbed habitats compared to less disturbed habitats. The sparse canopy cover in heavily disturbed forest probably increases the amount of heat (infrared) radiation reaching the forest floor, causing the water in swamp pools and at the base of large trees to evaporate. Although the study was conducted in mixed swamp lowland forest, pools were found at only two logged
TABLE 4 Covariates of a generalized linear model for the number of cassowaries encountered per transect. The model is Poisson distributed and was fitted using the Akaike information criterion.

\begin{tabular}{lrrl}
\hline Variable & \multicolumn{1}{c}{ Estimate } & \multicolumn{1}{c}{$Z$} & $\operatorname{Pr}(>|z|)$ \\
\hline Intercept & $-1.308 \pm$ SE 0.520 & -2.513 & 0.012 \\
Fruiting trees & $0.116 \pm$ SE 0.049 & 2.343 & 0.019 \\
Water sources & $0.395 \pm$ SE 0.178 & 2.221 & 0.026 \\
Fruiting trees*water & $-0.017 \pm$ SE 0.009 & -1.992 & 0.046 \\
$\quad$ & & & \\
\hline
\end{tabular}

forest sites during the survey. Pools had probably disappeared from the other sites as a result of heat radiation and anthropogenic activities. As cassowaries require regular access to water throughout the year (Crome \& Moore, 1990) it is possible that individuals utilizing logged forest could suffer from a lack of water resources during the dry season. Although our findings indicate that northern cassowaries make use of disturbed habitat such as recently logged forest and forest gardens as they provide food resources, only primary and natural forest may provide sufficient food and water throughout the year.

The effect of forest disturbance on the northern cassowary may be exacerbated by hunting, facilitated by increased access to forest from logging roads. We found that hunting signs were more frequent in highly disturbed habitat, followed by secondary forest, but were absent in primary forest, seemingly because of the natural barrier formed by a river, which impeded access. Because of its large body size the northern cassowary is the main target bird species for meat consumption among the Genyem tribe in Jayapura region, and its meat is traded in local markets (Pangau-Adam \& Noske, 2010).

\section{Conservation implications}

We estimate the population of adult cassowaries in our study area to be $851-1,652$ (95\% CI), and therefore the Nimbokrang lowlands are a potentially important region for cassowary conservation. Both northern and southern 
TABLE 5 Habitat and forest-type classification for lowland forest in the Jayapura region of Papua, Indonesia, including designated conservation areas (data based on Landsat images from 2009 reported by the Agency for Forestry Area Consolidation (BPKH) Papua, 2010).

\begin{tabular}{lcccc}
\hline Forest type/land use & $\begin{array}{l}\text { Protection } \\
\text { forest }\end{array}$ & $\begin{array}{l}\text { Production } \\
\text { forest }\end{array}$ & $\begin{array}{l}\text { Conversion } \\
\text { forest }\end{array}$ & $\begin{array}{l}\text { Designated } \\
\text { conservation areas }\end{array}$ \\
\hline Primary forest $\left(\mathrm{km}^{2}\right)$ & 4,592 & 2,558 & 1,802 & 209 \\
Primary swamp forest $\left(\mathrm{km}^{2}\right)$ & 458 & 449 & 399 & 0 \\
Secondary swamp forest & 0 & 12 & 57 & 0 \\
$\left(\mathrm{~km}^{2}\right)$ & 269 & 1,028 & 561 & 0 \\
Secondary forest $\left(\mathrm{km}^{2}\right)$ & 0 & 0 & 1.4 & 1 \\
Mangrove forest $\left(\mathrm{km}^{2}\right)$ & 18 & 54 & 145 & 15 \\
Mixed agriculture $\left(\mathrm{km}^{2}\right)$ & 5,337 & 4,101 & 2,966 & $225^{*}$ \\
Total & & & & \\
\hline
\end{tabular}

${ }^{\star}$ Mt Cyclops Nature Reserve

cassowaries are categorized as Vulnerable and the dwarf cassowary as Near Threatened on the IUCN Red List (IUCN, 2013). The Australian population of the southern cassowary is threatened by habitat fragmentation and housing development (Latch, 2007). In Papua New Guinea all three species are already extirpated from several regions as a result of habitat destruction and overhunting (Beehler et al., 1995; Johnson et al., 2004; Wright, 2005). The decline and loss of cassowaries may affect the abundance and risk of extinction of forest flora that depend on these frugivores to disperse their seeds. In turn, because cassowaries depend on the fruit of rainforest trees for their survival (Stocker \& Irvine, 1983; Mack \& Dumbacher, 2007), loss of their food plant species may lead to their extirpation.

The forests of northern Papua, including protection forests, have increasingly been exploited for timber, and cleared for plantations and settlements, accelerated by the special regional autonomy laws enacted in 2001, which allow local authorities to determine the exploitation of natural resources (de Fretes, 2007). Moreover, the only conservation area with law enforcement staff in this region, the Mt Cyclops Nature Reserve, is only c. $225 \mathrm{~km}^{2}$ (Table 5) and even there the majority of the foothills have already been converted to small-scale agriculture and settlements. Such imminent forest conversion underlines the importance of law enforcement to prohibit illegal logging in northern Papua and to maintain healthy populations of the northern cassowary in the long term. We propose the establishment of strictly controlled and guarded conservation areas. By law, forests can be upgraded to conservation areas (nature reserves and wildlife reserves) if they are home to unique biodiversity and have significant ecosystem functions (Government Regulation, PP RI No. 68/1998). Enforcing the protection of conservation areas in Papua generates conflicts between government and traditional communities (de Fretes, 2007), and therefore it is important that local communities are engaged in the establishment of such areas. Most lowland forests in the Jayapura region are designated as production and conversion forest but parts of Nimbokrang, Unurumguay and Nimboran forests should be upgraded to protected areas (e.g. wildlife reserves) because the region still supports large populations of the northern cassowary and is home to many other range-restricted birds and marsupials, and there is already a functioning cooperation between researchers from Cenderawasih University and the local tribes. This cooperation will be instrumental in securing the support of indigenous tribes for the preservation of traditional land rights and development of protected areas. University staff and Nature Conservation Agency Papua have already conducted an interactive workshop with local communities to examine the value of forest and the possibility of establishing a nature reserve, and local people have expressed an interest in maintaining forest ecosystem services and supporting the protection of Nimbokrang forest.

\section{Acknowledgements}

This study was funded by the Dorothea Schlözer Fellowship Programme, University of Göttingen. MW is supported by a grant from the Volkswagen Foundation, Hanover. We thank Richard Noske for his useful suggestions on the manuscript.

\section{References}

Agency for Forestry Area Consolidation (BPKH) Papua (2010) Luas penutupan lahan 2009 pada fungsi kawasan hutan provinsi Papua. Unpublished report. BPKH Jayapura Papua, Indonesia.

Beehler, B.M., Pratt, T.K. \& Zimmerman, D.A. (1986) Birds of New Guinea. Princeton University Press, Princeton, USA.

Beehler, B.M., Sengo, J.B., Filardi, C. \& Merg, K. (1995)

Documenting the lowland rainforest avifauna in Papua 
New Guinea-effects of patchy distributions, survey effort and methodology. Emu, 95, 149-161.

BentrupperbäUmer, J. (1997) Reciprocal ecosystem impact and behavioural interactions between cassowaries, Casuarius casuarius, and humans, Homo sapiens: exploring the natural-human environment interface and its implications for endangered species recovery in north Queensland, Australia. PhD thesis. James Cook University, Townsville, Australia.

BirdLife International (2013) Northern cassowary Casuarius unappendiculatus. Http://www.birdlife.org/datazone/ speciesfactsheet.php?id=6 [accessed 21 February 2013].

Buckland, S.T., Anderson, D.R., Burnham, K.P., LaAke, J.L., Borchers, D.L. \& Thomas, L. (2001) Introduction to Distance Sampling: Estimating Abundance of Biological Populations. Oxford University Press, Oxford, UK.

Castelletta, M., Sodhi, N.S. \& Subaraj, R. (2000) Heavy extinctions of forest avifauna in Singapore: lessons for biodiversity conservation in Southeast Asia. Conservation Biology, 14, 1870-1880.

Contes, B.J. (1985) The Birds of Papua New Guinea. Volume 1: Non-Passerines. Dove Publications, Alderley, Australia.

Crome, H.J. (1976) Some observations on the biology of the cassowary in northern Queensland. Emu, 76, 8-14.

Crome, H.J. \& Moore, L.A. (1990) Cassowaries in north-eastern Queensland: report of a survey and a review and assessment of their status and conservation and management needs. Australian Wildife Research, 17, 369-385.

de Fretes, Y. (2007) The protected area system in Papua. In The Ecology of Papua: Part Two (eds A.J. Marshall \& B.M. Beehler), pp. 1251-1275. Periplus Editions, Singapore.

Fahrmeir, L., Künstler, R., Pigeot, I. \& Tutz, G. (2010) Statistik: Der Weg zur Datenanalyse. Springer, Heidelberg, Germany.

Forestry Services of Papua Province (2001) The Forestry Condition in Papua Province. Presented at Forestry Workshop of Papua Province, Jayapura, Indonesia.

Frazier, S. (2007) Threats to biodiversity. In The Ecology of Papua: Part Two (eds A.J. Marshall \& B.M. Beehler), pp. 1199-1229. Periplus Editions, Singapore.

Gomes, L.G.L., Oostra, V., Nijman, V., Cleeef, A.M. \& Kappelle, M. (2008) Tolerance of frugivorous birds to habitat disturbance in a tropical cloud forest. Biological Conservation, $141,860-871$.

Government Regulation (1998) Peraturan Pemerintah RI No. 68 Tentang Kawasan Suaka Alam dan Kawasan Pelestarian Alam. Pemerintah, Indonesia.

InNIS, G.J. (1989) Feeding ecology of fruit pigeons in subtropical rainforests of south-eastern Queensland. Australian Wildlife Research, 16, 365-394.

IUCN (2013) IUCN Red List of Threatened Species v. 2013.1. Http:// www.iucnredlist.org [accessed 7 August 2013].

Johnson, A., BINO, R. \& IGAG, P. (2004) A preliminary evaluation of the sustainability of cassowary (Aves: Casuariidae) capture and trade in Papua New Guinea. Animal Conservation, 7, 129-137.

Kattan, G.H., Alvarez-Lopez, H. \& Giraldo, M. (1994) Forest fragmentation and bird extinctions: San Antonio eighty years later. Conservation Biology, 8, 138-146.

Latch, P. (2007) National Recovery Plan for the Southern Cassowary Casuarius casuarius johnsonii. Report to Department of the Environment, Water, Heritage and the Arts, Canberra, Australia.
LeFEVRE, K.L. (2008) The influence of human disturbance on avian frugivory and seed dispersal in a Neotropical rainforest. $\mathrm{PhD}$ thesis. University of Toronto, Canada.

MACK, A.L. \& Wright, D. (2005) The frugivore community and the fruiting plant flora in a New Guinea rainforest: identifying keystone frugivores. In Tropical Fruits and Frugivores: The Search for Strong Interactors (eds J.L. Dew \& J.P. Boubli), pp. 185-203. Springer, Dordrecht, The Netherlands.

Mack, L.M. \& Dumbacher, J. (2007) Birds of Papua. In The Ecology of Papua: Part One (eds A.J. Marshall \& B.M. Beehler), pp. 654-688. Periplus Editions, Singapore.

Mack, L.M. \& West, P. (2005) The Thousand Tonnes of Small Animals: Wildife Consumption in Papua New Guinea, a Vital Resource in Need of Management. Resource Management in Asia-Pacific Working Paper No. 61. Resource Management in Asia-Pacific Programme, Canberra, Australia.

Moore, L. (2003) Ecology and population viability analysis of the Southern cassowary Casuarius casuarius johnsonii, Mission Beach, north Queensland. MSc thesis. James Cook University, Townsville, Australia.

Moore, L. (2007) Population ecology of the southern cassowary (Casuarius casuarius johnsonii), Mission Beach, north Queensland. Journal of Ornithology, 148, 357-366.

Pangau-Adam, M. \& Noske, R. (2010) Wildlife hunting and bird trade in northern Papua. In Ethno-ornithology: Global Studies in Indigenous Ornithology, Culture, Society and Conservation (eds S. Tidemann, A. Gosler \& R. Gosford), pp. 73-85. Earthscan, London, UK.

R Development Core Team (2011) R: A Language and Environment for Statistical Computing. R Foundation for Statistical Computing, Vienna, Austria.

Stocker, G.C. \& Irvine, A.K. (1983) Seed dispersal by cassowaries (Casuarius casuarius) in north Queensland's rainforests. Biotropica, $15,170-176$

TAKeUChI, W.N. (2007) Introduction to the flora of Papua. In The Ecology of Papua: Part One (eds A.J. Marshall \& B.M. Beehler), pp. 269-302. Periplus Editions, Singapore. Waltert, M., Mardiastuti, A. \& Muehlenberg, M. (2004) Effects of land use on bird species richness in Sulawesi, Indonesia. Conservation Biology, 18, 1339-1346.

Wright, D. (2005) Diet, keystone resources and altitudinal movement of dwarf cassowaries in relation to fruiting phenology in a Papua New Guinean rainforest. In Tropical Fruits and Frugivores: The Search for Strong Interactors (eds J.L. Dew \& J.P. Boubli), pp. 205-236. Springer, Dordrecht, The Netherlands.

\section{Biographical sketches}

MARgaretha PANGAU-ADAM is running a research project on the northern cassowary in Papua, Indonesia. She is interested in frugivores and seed dispersal, ecosystem functioning and biodiversity conservation. Michael Mühlenberg's research interests lie in the management of protected areas, tropical ecology and conservation biology. Mat thi is WALTERT studies the effects of forest land use on tropical biodiversity and teaches international nature conservation and wildlife assessment to university students. 